\title{
Taxonomy and distribution of the sigmodontine rodents of genus Necromys in central Argentina and Uruguay
}

\author{
Carlos A. GALLIARI and Ulyses F. J. PARDIÑAS*
}

Galliari C. A. and Pardiñas U. F. J. 2000. Taxonomy and distribution of the sigmodontine rodents of genus Necromys in central Argentina and Uruguay. Acta Theriologica 45: 211-232.

The taxonomic status of the species of Necromys Ameghino, 1889 (= Bolomys Thomas, part), inhabiting the pampean region of Argentina and southern Uruguay is not clear. The two most recent systematic hypotheses both distinguish two species. Massoia and Fornes (1967) recognized Necromys obscurus (Waterhouse, 1837) with allopatric populations in southern Uruguay and southeastern Buenos Aires Province (Argentina), and $N$. benefactus (Thomas, 1919) distributed in a strip across northwestern-southwestern Buenos Aires Province. Reig (1987) argued that the populations of Uruguay and northwestern Buenos Aires Province belong to $N$. obscurus (including $N$. benefactus as a subspecies), while those of the southeast and southwest are referred to an unnamed taxon. To solve this problem, 152 specimens from Argentina and Uruguay were studied using morphometric data and qualitative characters. Craniodental variables were measured in 97 adult specimens of both sexes. Discriminant-function analysis among preestablished geographic groups and cluster analysis using Mahalanobis distances revealed the presence of two groups with contrasting morphological characteristics. The first group, which corresponds to $N$. benefactus, includes the populations from northern La Pampa, southern Santa Fé, and northwestern, centralwest, and southwestern Buenos Aires Province (Argentina). The second group, N. obscurus, includes the populations from Uruguay ( $N$. obscurus obscurus) and from southeastern Buenos Aires Province (a new subspecies).

Jardín Zoológico de La Plata, Avenida 52 y 118, 1900 La Plata, Argentina (CAG) Departamento Científico Paleontología Vertebrados, Museo de La Plata, Paseo de Bosque s/n, 1900 La Plata, Argentina, e-mail: ulyses@netverk.com.ar (UFJP)

Key words: Necromys, Bolomys, Rodentia, Sigmodontinae, taxonomy, pampas

\section{Introduction}

During the past decade, new species and genera of sigmodontine rodents were discovered in South American regions believed to be mammalogically well known (eg Hershkovitz 1990, Patterson 1992, Braun and Mares 1995). This fact shows the incomplete knowledge of the composition of the micromammal assemblages in wide regions, and challenges our interpretation of speciation processes and biogeographic history. A solid alpha-systematic base is essential to phylogenetic and biogeographic hypotheses (Voss 1988).

\footnotetext{
* Corresponding author
} 
Muroid rodent communities from central-eastern Argentina and southern Uruguay are thought to be well known within South America's Southern Cone (eg Reig 1965, Massoia and Fornes 1967, Ximénez et al. 1972, Massoia 1976). However, a detailed analysis of the available information reveals that numerous taxonomic topics remain unresolved (Reig 1987, Musser and Carleton 1993, Galliari et al. 1996). Among them are the status of Scapteromys tumidus (Waterhouse, 1837) vs S. aquaticus Thomas, 1920; Oxymycterus platensis Thomas, 1920 vs O. rufus (Fischer, 1814); the subspecies of Akodon azarae (Fischer, 1829), or those entities included in the genus Necromys Ameghino, 1889.

The genus Necromys (= Bolomys Thomas, 1916), excluding Bolomys amoenus Thomas, 1916 and Akodon albiventer Thomas, 1897 (see below), has approximately 13 nominal forms, ranging from northeastern Brazil to middle latitudes of Argentina and Uruguay (see Voss 1991 for a discussion of the presence of Necromys in Ecuador). In Argentina, N. temchuki (Massoia, 1980) has been cited for the northeast, $N$. lactens (Thomas, 1918) in the northwestern ranges, $N$. lasiurus (Lund, 1841) in Misiones, $N$. lenguarum (Thomas, 1898) in the Chacoan region, and $N$. obscurus (Waterhouse, 1837), including $N$. benefactus (Thomas, 1919), in the pampean region. The taxonomic status of $N$. obscurus is perhaps the most complex of all these species. Two hypotheses have been proposed; Massoia and Fornes (1967) argued in favor of the existence of two species, $N$. obscurus for to the populations in southern Uruguay and southeastern Buenos Aires Province and $N$. benefactus for those in northwestern Buenos Aires Province. In turn, Reig (1987) argued that those populations from Uruguay and southern Santa Fé, Córdoba, northern La Pampa, and northwestern Buenos Aires (Argentina) belong to the species $N$. obscurus (including $N$. benefactus as a subspecies), while those from southeastern and southwestern Buenos Aires Province represent a new species. Reig (1972) referred to the latter as "Bolomys scagliarum", although never published, and subsequently treated the some populations as "Bolomys sp. C" in a posthumous publication (Reig 1994). Results of our work redefine the distribution of Necromys species in this region, generally in accordance with the views of Massoia and Fornes (1967). Taxa are redescribed based on morphological and morphometric characters.

\section{Material and methods}

We studied 152 specimens collected in 22 localities from central Argentina and southern Uruguay (see Appendix). Specimens were classified according to the occlusal wear of the upper molars, as follows: (1) $\mathrm{M}^{3}$ erupted without wear, (2) $\mathrm{M}^{3}$ with moderate wear, retaining the paraflerus and mesoflexus, (3) $\mathrm{M}^{3}$ with paraflexus and mesoflexus closed, and (4) $\mathrm{M}^{2}$ with paraflexus lost (Fiz. 1).

External measurement were taken from the collector label: length of head and body (HBL), length of tail (TL), length of ear (EL), and length of hindfoot (HFL). The following cranial and mardibular variables were measured with digital caliper (to the nearest $0.02 \mathrm{~mm}$ ) and a micrometrical ocuar on a stereoscope: condylobasal length (CBL), length of upper diastema (DIL), palatal length (PAL), palatal width at $\mathrm{M}^{1}$ level (WP1), palatal width at $\mathrm{M}^{3}$ level (WP2), maximum length of incisive foramina (IFL), 

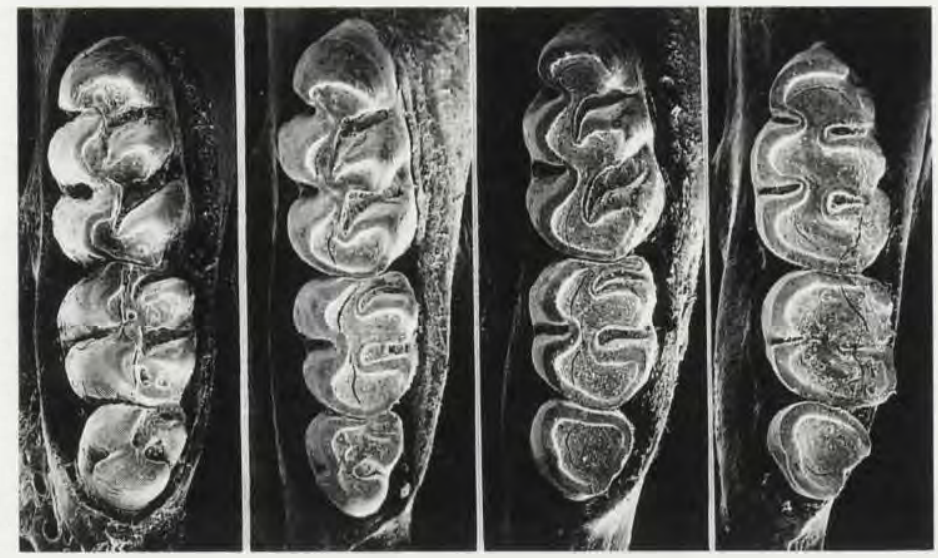

Fig. 1. Examples of four molar toothwear classes, from left to right, of Necromys benefactus from Sierra de la Ventana (Buenos Aires Province, Argentina): toothwear class 1 (MLP 15-II-96-12), toothwear class 2 (MLP 15-II-96-22), toothwear class 3 (MLP 15-II-96-10), and toothwear class 4 (MLP 15-II-96-36).

maximum width of incisive foramen (IFW), rostral width at the tips of the nasolacrimal capsules (ROB), length of rostrum from anteriormost point of nasal to the anterior margin of lacrimal bone (ROL), minimum interorbital width (IOC), maximum bizygomatic width (BZW), length of nasal suture (NAL), length of frontal suture (FRL), width of mesopterygoid fossa at the level of presphenoid-basisphenoid suture (MFW), width of braincase at the beginning of the hamular process (BCW), posterior expansion of the frontal (EPF), width of zygomatic plate (ZPW), height of zygomatic plate (ZPH), maximal width of nasals (NAW), maximal length of mandible without incisor (MAL), and length of lower diastema (DLI). Maximal length and width of crown were measured for upper and lower molars: $M^{1} L, M^{1} W, M^{2} L, M^{2} W, M^{3} L, M^{3} W$, and $M_{1} L, M_{1} W, M_{2} L, M_{2} W, M_{3} L, M_{3} W$. Length of upper (UMR) and lower (LMR) molar series were taken at the edge of the alveoli. The large number of variables are necessary to study fossil remains in the future, because many common measures cannot be employed due to fragmentary nature of fossils. External measures of museum skins were not considered for the statistical analysis in view of the error caused in measurements by different collectors (Santos Moreno 1994), and the lack of these data for several specimens.

The morphometric analysis was based on a subset of 97 adult specimens (from 12 localities, see Appendix). Five groups were defined (Fig. 2) by geographic proximity and environmental conditions (eg coastal grassland vs highlands): northeastern Buenos Aires Province (EST), southeastern Buenos Aires Province (coastal grassland, SES), Tandil and Balcarce highlands (TAN), Ventana ranges (VEN) and Uruguay (URU). This cluster of localities was need to increase the size of samples for the statistical analysis and to conduct the population study independently from previous taxonomic proposals. A few specimens coming from other localities were not included within these groups, and their relationship to each of the five groups was assessed by the statistical analysis.

Only specimens with less than five missing values were used in the analyses. The missing data were replaced by the group's mean across localities. Variables were transformed to their natural logarithms (Marcus 1990). Normality of the variables was checked by visually plotting the observed residuals vs the standarized values ( $z$-values) of the residues' normal distribution.

Literature on Necromys species indicate morphometric differences among ages and sexes (Macedo and Mares 1987). Consequently, only adult specimens of pooled dental ages 3 and 4 , were analyzed (Table 1). We pooled the sexes, as the samples showed a balanced male:female ratio (see Appendix) and males were $<3 \%$ larger than females. This permitted larger samples. 


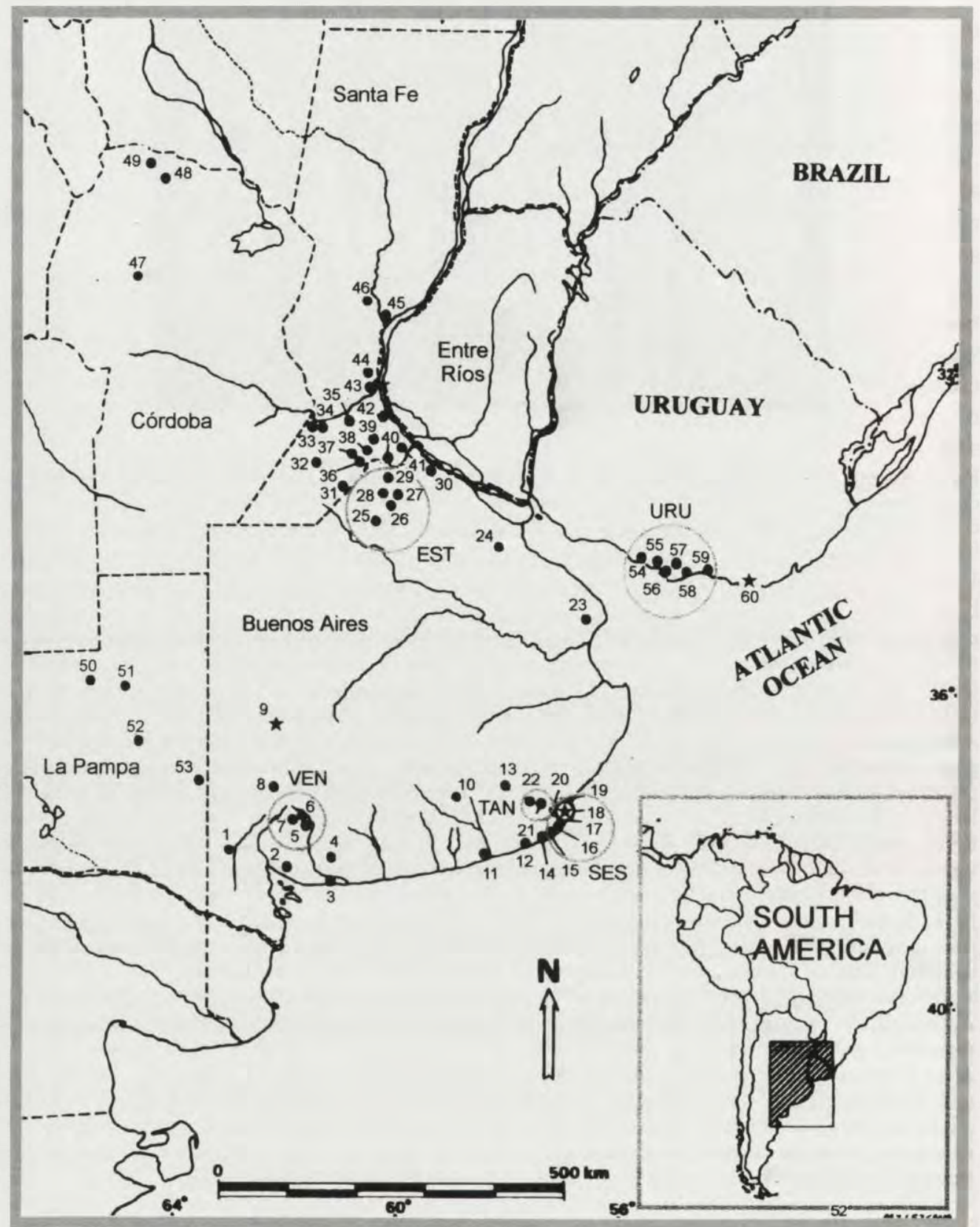

Fig. 2. Localities of occurrence of Necromys in central Argentina and southern Uruguay (see the Appendix for the number of each locality). Stars indicate type localities of taxa treated herein: Necromys benefactus (9); $N$. obscurus obscurus (60), and $N$. obscurus scagliarum subsp. nov. (18). Major circles indicate geographic groups employed in the morphometric analysis (see p. 213 for explanation of abbreviations). 
The software STATISTICA (StatSoft, Inc. 1995) was employed. Univariate analyses of variance (ANOVA) were performed to evaluate differences among geographic groups. Later, the Student-Newman-Keuls (SNK) test was used to compare differences in means of each variable among groups (Sokal and Rohlf 1981). The discriminant function analysis (DFA), under the step-wise option, was used to identify the best variables for discriminating groups. Because the sample size of each group differed, a classification based on Mahalanobis distances was made wherein each specimen had a priori the same probability of group assignement, independent of sample size. Specimens not included within the five preestablished groups were classified using the a posteriori group probabilities. Later, the discriminant canonical function was used to reduce the multivariate space to the first three canonical roots and calculate the canonical coefficients for the first three eigenvectors derived from discriminant analyses. Employing canonical coefficients, the scores of all the specimens were computed and plotted using canonical roots as axes. Phenetic relations among groups were studied by cluster analysis using Mahalanobis mean distances between centroids and the unweighted pair-group method using arithmetic averages (UPGMA).

In order to update the distribution of Necromys, incomplete mandibles and skulls from owl pellets, were studied. Furthermore, all localities mentioned in the literature were included (see Appendix).

\section{Results}

\section{Morphometric analysis}

Except for the palatal width at $\mathrm{M}^{3}$ and width of the incisive foramina, all characters showed highly significant differences among geographic groups (Table 1). Nasal length, with $p<0.046$, bounds the significant probability values. Results of SNK tests showed variation in the number of variables showing significant differences between pairs of localities: EST vs SES (26 different variables), EST vs TAN (26), EST vs URU (24), SES vs VEN (24), URU vs VEN (23), and TAN vs VEN (22). The least number of differences occured between SES vs TAN (3) and VEN vs EST (11). In general specimens included in EST and VEN groups are smaller in both the craniodental and body variables than those of the other three groups (Table 1).

The discriminant-function analysis among groups yielded significant results (Wilks' lambda $=0.001, F=10.32, p<0.001, \mathrm{df}=108,264$ ). The step-wise analysis selected 27 variables of greatest discriminant power. Mahalanobis distances between centroids of each group were significantly different (Table 2). Classification functions (also called identification functions; Legendre and Legendre 1983) were in most cases $100 \%$ correct; only two specimens of the TAN group were misclassified as SES and vice-versa (Table 3). Classifications a posteriori on specimens from localities not included in the five preestablished groups (Fig. 2) showed that specimens from Fulton (locality \#13, see Appendix), Coronel Dorrego (\#4) and Monte Veloz (\#23) localities (Buenos Aires Province) were assigned with highest probabilities to VEN $(p=0.99)$, EST $(p=0.99)$, and VEN $(p=0.97)$, respectively. Specimens from southern Santa Fé Province (localities \#32, \#37, \#39, and \#46) were assigned with highest probability to $\operatorname{EST}(p=0.99)$, and those from Córdoba Province (\#48 and \#49) to VEN ( $p=0.85$ ). These results agree with the morphological analysis below. 
Table 1. Means, standard deviations, and sample size (in parenthesis) for craniodental variables and external measurements and weight in five geographical groups (see pp. 212-213 for explanation of abbreviations) of adult Necromys (measurements in mm, weights in g). ANOVA probabilities of differences among groups: ${ }^{*}-p<0.05,{ }^{* *}-p<0.01,{ }^{* * *}-p<0.001$, ns - not significant, na - not analyzed.

\begin{tabular}{|c|c|c|c|c|c|}
\hline \multirow{2}{*}{ Variable } & \multicolumn{2}{|c|}{ Necromys benefactus } & \multicolumn{2}{|c|}{ N. obscurus scagliarum subsp. nov. } & \multirow{2}{*}{$\begin{array}{c}\text { N. o. obscurus } \\
\text { URU }\end{array}$} \\
\hline & EST & VEN & SES & TAN & \\
\hline $\mathrm{CBL}^{* * *}$ & $26.22 \pm 1.00(21)$ & $26.48 \pm 0.84(20)$ & $28.40 \pm 0.72(32)$ & $28.23 \pm 1.19(12)$ & $28.64 \pm 1.81(4)$ \\
\hline $\mathrm{PAL}^{* * *}$ & $12.39 \pm 0.45(18)$ & $12.76 \pm 0.54(20)$ & $13.24 \pm 0.42(32)$ & $13.23 \pm 0.55(12)$ & $13.71 \pm 0.98(5)$ \\
\hline DIL*** & $7.64 \pm 0.43(24)$ & $7.83 \pm 0.40(21)$ & $7.98 \pm 0.28(35)$ & $8.01 \pm 0.50(12)$ & $8.51 \pm 0.61(5)$ \\
\hline WP1** & $3.37 \pm 0.28(24)$ & $3.31 \pm 0.25(21)$ & $3.55 \pm 0.22(35)$ & $3.44 \pm 0.35(12)$ & $3.68 \pm 0.12(5)$ \\
\hline WP2 ns & $2.47 \pm 0.19(24)$ & $2.49 \pm 0.17(21)$ & $2.44 \pm 0.21(35)$ & $2.45 \pm 0.16(12)$ & $2.54 \pm 0.15(5)$ \\
\hline $\mathrm{IFL}^{* * *}$ & $6.17 \pm 0.32(24)$ & $6.13 \pm 0.40(21)$ & $7.06 \pm 0.30(35)$ & $7.05 \pm 0.29(12)$ & $6.54 \pm 0.24(5)$ \\
\hline IFW ns & $1.85 \pm 0.18(24)$ & $1.79 \pm 0.10(21)$ & $1.81 \pm 0.12(35)$ & $1.72 \pm 0.18(12)$ & $1.81 \pm 0.11(5)$ \\
\hline $\mathrm{ROB}^{* * *}$ & $4.86 \pm 0.31(24)$ & $5.19 \pm 0.28(21)$ & $5.57 \pm 0.23(35)$ & $5.21 \pm 1.31(12)$ & $5.56 \pm 0.38$ \\
\hline ROL*** & $9.28 \pm 0.61(24)$ & $9.93 \pm 0.44(21)$ & $10.22 \pm 0.57(34)$ & $10.46 \pm 0.58$ & $10.28 \pm 0.70(5)$ \\
\hline $10 C^{* * *}$ & $4.48 \pm 0.22(24)$ & $4.66 \pm 0.19(21)$ & $4.76 \pm 0.19$ & $4.85 \pm 0.18(12)$ & $4.81 \pm 0.25$ \\
\hline $\mathrm{BZW}^{* * *}$ & $14.91 \pm 0.53(22)$ & $15.14 \pm 0.54$ & $16.52 \pm 0.61$ & $16.34 \pm 0.67(12)$ & $16.73 \pm 0.66(5)$ \\
\hline $\mathrm{NAL}^{*}$ & $8.81 \pm 0.68(24)$ & $9.30 \pm 0.78(20)$ & $9.00 \pm 0.22(32)$ & $9.32 \pm 0.85$ & $9.24 \pm 0.58(5)$ \\
\hline FRL ${ }^{* *}$ & $10.43 \pm 0.73(22)$ & $10.73 \pm 1.27(21)$ & $11.03 \pm 0.73(35)$ & $11.42 \pm 0.65(12)$ & $10.44 \pm 0.47(5)$ \\
\hline $\mathrm{MFW}^{* * *}$ & $1.30 \pm 0.11(23)$ & $1.35 \pm 0.19$ & $1.15 \pm 0.10$ & $1.16 \pm 0.16(12)$ & $1.28 \pm 0.19$ \\
\hline $\mathrm{BCW}^{* * *}$ & $12.28 \pm 0.21(22)$ & $12.51 \pm 0.27$ & $13.12 \pm 0.31$ & $13.10 \pm 0.21(12)$ & $12.83 \pm 0.37(4)$ \\
\hline $\mathrm{EPF}^{* * *}$ & $8.80 \pm 0.38(22)$ & $9.14 \pm 0.50(21)$ & $7.62 \pm 0.40(35)$ & $7.94 \pm 0.18$ & $7.85 \pm 0.26(5)$ \\
\hline $\mathrm{ZPW}^{* * * *}$ & $2.78 \pm 0.23(24)$ & $3.00 \pm 0.20(21)$ & $3.46 \pm 0.15(35)$ & $3.43 \pm 0.24(12)$ & $3.50 \pm 0.09(5)$ \\
\hline $\mathrm{ZPH}^{* * *}$ & $4.91 \pm 0.56(24)$ & $5.14 \pm 0.29(21)$ & $5,85 \pm 0.25(35)$ & $5.88 \pm 0.41(12)$ & $6.18 \pm 0.61(5)$ \\
\hline $\mathrm{NAW}^{* * *}$ & $3.16 \pm 0.16(13)$ & $3.14 \pm 0.16$ & $3.62 \pm 0.16(33)$ & $3.62 \pm 0.21(12)$ & $3.52 \pm 0.27(5)$ \\
\hline MAL $^{* * *}$ & $14.69 \pm 0.65(16)$ & $15.59 \pm 0.74(21)$ & $16.17 \pm 0.46$ & $15.95 \pm 0.54(12)$ & $16.78 \pm 0.93$ \\
\hline DLI*** & $3.43 \pm 0.32(16)$ & $3.52 \pm 0.25(21)$ & $3.81 \pm 0.24$ & $3.87 \pm 0.36$ & $4.06 \pm 0.28$ \\
\hline $\mathrm{M}^{1} \mathrm{~L}^{* * *}$ & $2.41 \pm 0.14(24)$ & $2.42 \pm 0.13(21)$ & $2.56 \pm 0.13(36)$ & $2.46 \pm 0.18$ & $2.26 \pm 0.06(5)$ \\
\hline $\mathrm{M}^{1} \mathrm{~W}^{* * * *}$ & $1.41 \pm 0.10$ & $1.37 \pm 0.06(21)$ & $1.52 \pm 0.10(36)$ & $1.51 \pm 0.14$ & $1.48 \pm 0.11(5)$ \\
\hline $\mathrm{M}^{2} \mathrm{~L}^{* * *}$ & $1.34 \pm 0.06(24)$ & $1.37 \pm 0.07(20)$ & $1.55 \pm 0.09(36)$ & $1.52 \pm 0.11(12)$ & $1.44 \pm 0.10$ \\
\hline $\mathrm{M}^{2} \mathrm{~W}^{* * *}$ & $1.38 \pm 0.11(24)$ & $1.30 \pm 0.07(21)$ & $1.50 \pm 0.11(36)$ & $1.48 \pm 0.10(12)$ & $1.46 \pm 0.13(5)$ \\
\hline $\mathrm{M}^{3} \mathrm{~L}^{* * *}$ & $0.85 \pm 0.08(24)$ & $0.81 \pm 0.08$ & $1.13 \pm 0.07$ & $1.01 \pm 0.07(12)$ & $1.08 \pm 0.09(5)$ \\
\hline $\mathrm{M}^{3} \mathrm{~W}^{* * *}$ & $1.10 \pm 0.10(24)$ & $1.04 \pm 0.07(21)$ & $1.18 \pm 0.06(35)$ & $1.13 \pm 0.06(12)$ & $1.20 \pm 0.11(5)$ \\
\hline UMR*** & $5.03 \pm 0.16(24)$ & $4.95 \pm 0.13(21)$ & $5.89 \pm 0.19(36)$ & $5.78 \pm 0.42(12)$ & $5.42 \pm 0.14(5)$ \\
\hline $\mathrm{M}_{1} \mathrm{~L}^{* * *}$ & $1.86 \pm 0.08(16)$ & $1.96 \pm 0.08(20)$ & $2.16 \pm 0.12(36)$ & $2.14 \pm 0.10(12)$ & $2.06 \pm 0.06(5)$ \\
\hline $\mathrm{M}_{1} \mathrm{~W}^{* * *}$ & $1.19 \pm 0.07(16)$ & $1.27 \pm 0.05(21)$ & $1.33 \pm 0.06(36)$ & $1.31 \pm 0.06(12)$ & $1.21 \pm 0.05(5)$ \\
\hline $\mathrm{M}_{2} \mathrm{~L}^{* * *}$ & $1.51 \pm 0.08(16)$ & $1.54 \pm 0.06(21)$ & $1.70 \pm 0.06(36)$ & $1.63 \pm 0.07(12)$ & $1.53 \pm 0.07(5)$ \\
\hline $\mathrm{M}_{2} \mathrm{~W}^{* * *}$ & $1.21 \pm 0.08(16)$ & $1.26 \pm 0.06(21)$ & $1.43 \pm 0.07(36)$ & $1.41 \pm 0.05(12)$ & $1.27 \pm 0.07(5)$ \\
\hline $\mathrm{M}_{3} \mathrm{~L}^{* * *}$ & $1.34 \pm 0.09(16)$ & $1.26 \pm 0.09(21)$ & $1.55 \pm 0.08(36)$ & $1.44 \pm 0.09(12)$ & $1.44 \pm 0.09(5)$ \\
\hline $\mathrm{M}_{3} \mathrm{~W}^{* * *}$ & $1.03 \pm 0.07(16)$ & $1.05 \pm 0.04(21)$ & $1.20 \pm 0.06(36)$ & $1.21 \pm 0.10(12)$ & $1.11 \pm 0.08(5)$ \\
\hline $\mathrm{LMR}^{* * * *}$ & $4.97 \pm 0.17(16)$ & $4.94 \pm 0.15(21)$ & $5.85 \pm 0.23(36)$ & $5.65 \pm 0.27(12)$ & $5.25 \pm 0.09$ \\
\hline HBL na & $166.75 \pm 9.10(28)$ & $169.04 \pm 13.98(27)$ & $174.17 \pm 10.17(12)$ & $187.29 \pm 11.87(17)$ & $192.75 \pm 23.99(4)$ \\
\hline TL na & $64.96 \pm 4.93(28)$ & $63.81 \pm 7.91(26)$ & $68.08 \pm 4.68(12)$ & $72.00 \pm 5.23(17)$ & $76.50 \pm 995$ \\
\hline EL na & $13.52 \pm 0.85(31)$ & $14.30 \pm 1.96(22)$ & $14.51 \pm 1.05(12)$ & $14.31 \pm 0.75(17)$ & $15.13 \pm 1.03(4)$ \\
\hline HFL na & $18.68 \pm 0.87(31)$ & $21.96 \pm 1.41(25)$ & $22.83 \pm 1.21(11)$ & $24.46 \pm 0.81(17)$ & $22.33 \pm 1.54(4)$ \\
\hline W na & $32.03 \pm 7.14(15)$ & $31.30 \pm 5.60(22)$ & $43.45 \pm 11.33$ & $43.65 \pm 11.05$ & - \\
\hline
\end{tabular}


Table 2. Squared Mahalanobis distances between five geographic groups (see p. 213 for explanation of abbreviations) of Necromys above diagonal; $p$-levels of $F$ values associated with the respective distances below diagonal.

\begin{tabular}{lccccc}
\hline Group & EST & VEN & SES & TAN & URU \\
\hline EST & - & 29.03 & 144.28 & 118.50 & 88.61 \\
VEN & 0.005 & - & 179.12 & 140.96 & 114.75 \\
SES & 0.005 & 0.005 & - & 10.79 & 59.19 \\
TAN & 0.005 & 0.005 & $<0.01$ & - & 56.13 \\
URU & 0.005 & 0.005 & 0.005 & 0.005 & - \\
\hline
\end{tabular}

Table 3. Classification matrix of specimens belonging to five geographic groups (see p. 213 for explanation of abbreviations) of Necromys.

\begin{tabular}{lcrrrrr}
\hline \multirow{2}{*}{ Observed } & $\begin{array}{c}\text { Percent } \\
\text { correct }\end{array}$ & \multicolumn{5}{c}{ Predicted } \\
\cline { 3 - 7 } & & EST & VEN & SES & TAN & URU \\
\hline EST & 100 & 24 & 0 & 0 & 0 & 0 \\
VEN & 100 & 0 & 21 & 0 & 0 & 0 \\
SES & 94.29 & 0 & 0 & 33 & 2 & 0 \\
TAN & 83.33 & 0 & 0 & 2 & 10 & 0 \\
URU & 100 & 0 & 0 & 0 & 0 & 5
\end{tabular}

Table 4. Eigenvalues and Wilks' lambda of the four canonical roots. $\chi^{2}$-test and probabilities with successive roots removed.

\begin{tabular}{lrccc}
\hline Root removed & Eigenvalue & Wilks' lambda & \multicolumn{1}{c}{$\chi^{2}(\mathrm{df})$} & $p$ \\
\hline 0 & 33.47 & 0.0014 & $524.36(108)$ & $<0.005$ \\
1 & 3.26 & 0.050 & $238.87(78)$ & $<0.005$ \\
2 & 1.77 & 0.214 & $122.97(50)$ & $<0.005$ \\
3 & 0.68 & 0.60 & $41.37(24)$ & 0.015 \\
\hline
\end{tabular}

The first three canonical functions were significant (Table 4); the first one accounts for $85.8 \%$ of the total variance. Length of lower and upper molar row, length of $\mathrm{M}^{3}$, and the posterior expansion of the frontals are the variables most correlated with canonical root 1 , which contributes to distinguishing groups SES, TAN, and URU from VEN and EST. Rostral width, width of $\mathrm{M}_{1}$ and width of zygomatic plate correlate more highly with canonical root 2, and separate EST from VEN, whereas the maximal length of mandible, the palatal length and height and width 
Table 5. Correlations (pooled within groups) between variables and canonical roots.

\begin{tabular}{lrrrr}
\hline Variable & Root 1 & Root 2 & Root 3 & Root 4 \\
\hline LMR & $-\mathbf{0 . 3 7 6}$ & -0.068 & 0.172 & 0.200 \\
EPF & $\mathbf{0 . 2 7 8}$ & -0.110 & 0.111 & -0.118 \\
ZPW & -0.236 & $-\mathbf{0 . 2 7 0}$ & $-\mathbf{0 . 2 7 0}$ & -0.008 \\
$\mathrm{M}_{3} \mathrm{~L}$ & -0.235 & 0.190 & 0.017 & $\mathbf{0 . 2 8 6}$ \\
$\mathrm{BCW}$ & -0.225 & -0.231 & -0.110 & -0.037 \\
$\mathrm{M}_{2} \mathrm{~W}$ & -0.255 & -0.232 & 0.171 & 0.110 \\
$\mathrm{M}^{3} \mathrm{~W}$ & -0.122 & 0.149 & -0.138 & 0.095 \\
$\mathrm{M}^{1} \mathrm{~L}$ & -0.066 & -0.051 & 0.268 & $\mathbf{0 . 2 7 6}$ \\
MAL & -0.137 & -0.263 & $-\mathbf{0 . 3 4 8}$ & 0.108 \\
IFL & -0.231 & -0.053 & 0.083 & -0.089 \\
PAL & -0.121 & -0.178 & $-\mathbf{0 . 2 8 3}$ & -0.053 \\
CBL & -0.182 & -0.120 & -0.208 & -0.045 \\
UMR & $-\mathbf{0 . 3 6 1}$ & -0.028 & 0.083 & 0.025 \\
$\mathrm{M}^{2} \mathrm{~W}$ & -0.138 & 0.120 & 0.006 & -0.033 \\
IFW & 0.014 & 0.104 & -0.012 & 0.239 \\
$\mathrm{M}_{1} \mathrm{~L}$ & -0.191 & -0.199 & -0.026 & 0.011 \\
WP2 & 0.018 & -0.013 & -0.082 & -0.031 \\
ZPH & -0.213 & -0.122 & $-\mathbf{0 . 3 2 6}$ & -0.056 \\
BZW & -0.217 & -0.117 & -0.258 & -0.007 \\
M $^{3} \mathrm{~L}$ & $-\mathbf{0 . 3 0 6}$ & 0.097 & -0.183 & $\mathbf{0 . 2 8 3}$ \\
$\mathrm{M}_{3} \mathrm{~W}$ & -0.219 & -0.132 & 0.069 & -0.088 \\
ROB & -0.174 & $-\mathbf{0 . 2 9 0}$ & -0.175 & -0.050 \\
M $\mathrm{H}$ W & -0.133 & $-\mathbf{0 . 2 7 5}$ & 0.164 & 0.202 \\
DIL & -0.058 & -0.084 & -0.269 & -0.058 \\
WP1 & -0.065 & 0.054 & -0.145 & 0.094 \\
NAL & -0.004 & -0.164 & -0.077 & -0.127 \\
IOC & -0.087 & -0.212 & -0.126 & -0.164 \\
& & & &
\end{tabular}
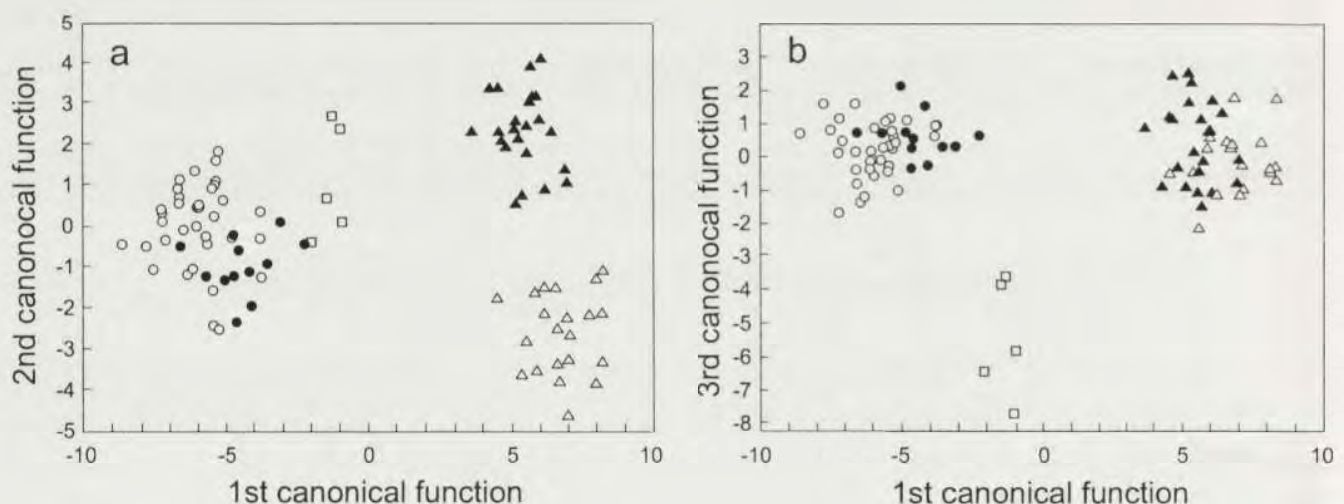

Fig. 3. Scatterplots of canonical variates derived from five geographic groups of Necromys from Argentina and Uruguay: a - 1st canonical function vs 2nd canonical function; b - 1st canonical function vs 3rd canonical function. $\boldsymbol{\Delta}$ - EST, $\mathrm{O}$ - SES, [ - URU, $\Delta$ - VEN, - TAN (see p. 213 for explanation of these abbreviations). 


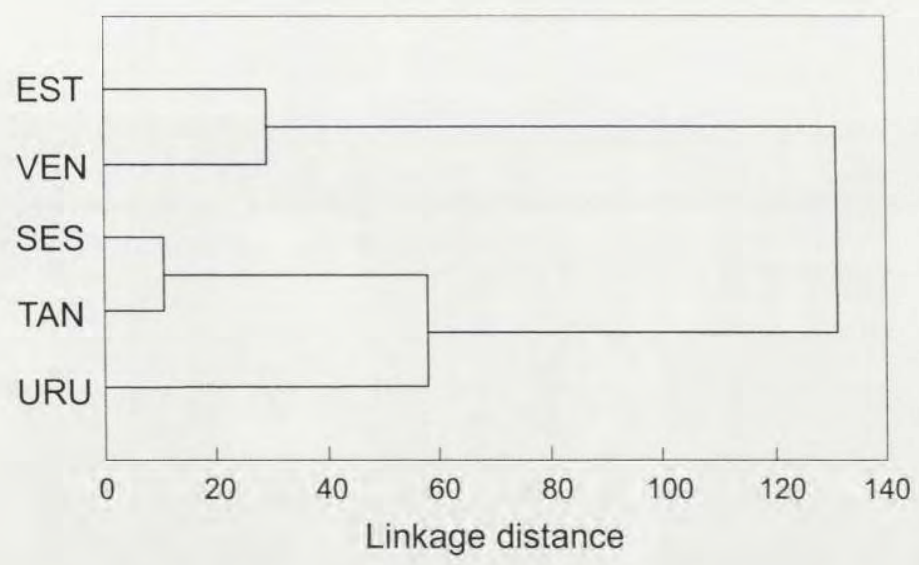

Fig. 4. Unweighted pair-group average clustering of Mahalanobis distances among five geographic groups of Necromys from Argentina and Uruguay (see p. 213 for explanation of abbreviations).

of the zygomatic plate correlate better with canonical root 3, which separates SES and TAN from URU (Table 5, Fig. 3). The resulting phenogram of Mahalanobis distances among centroids of the five groups indicates two major clusters, one formed by EST and VEN and the other by URU, SES and TAN, the latter two together in a subcluster (Fig. 4).

\section{Systematics}

On the basis of morphometric analysis, two main groups can be recognized: one formed by the geographic groups URU, TAN and SES, and the other by EST and VEN. These results agree with the analyses of qualitative characters and distinguish two taxa, to which the binomials $N$. obscurus and $N$. benefactus may be attributed. With regards to specimens not included in the statistical analysis (Appendix), their identification was determined upon morphology and individual measurements.

The large phenetic distances between URU and SES+TAN (Fig. 4) suggests a new taxon in southeastern Buenos Aires Province. The morphological distinctiveness of these populations is conservatively treated as a new subespecies until new information can clarify their level of divergence from $N$. obscurus proper.

\section{Necromys obscurus scagliarum nov, subsp.}

(Figs 2, 5, 6, and 7)

S y n o n y m y. Zygodontomys obscurus (sensu Hershkovitz, 1962, part) Cabreramys obscurus Massoia and Fornes, 1967 (part)

Bolomys sp. (sensu Reig, 1978, part; Reig, 1987, part)

Necromys obscurus (sensu Massoia, 1985, part)

Necromys obscurus (sensu Massoia and Pardinas, 1993, part)

Bolomys sp. C (sensu Reig, 1994) 


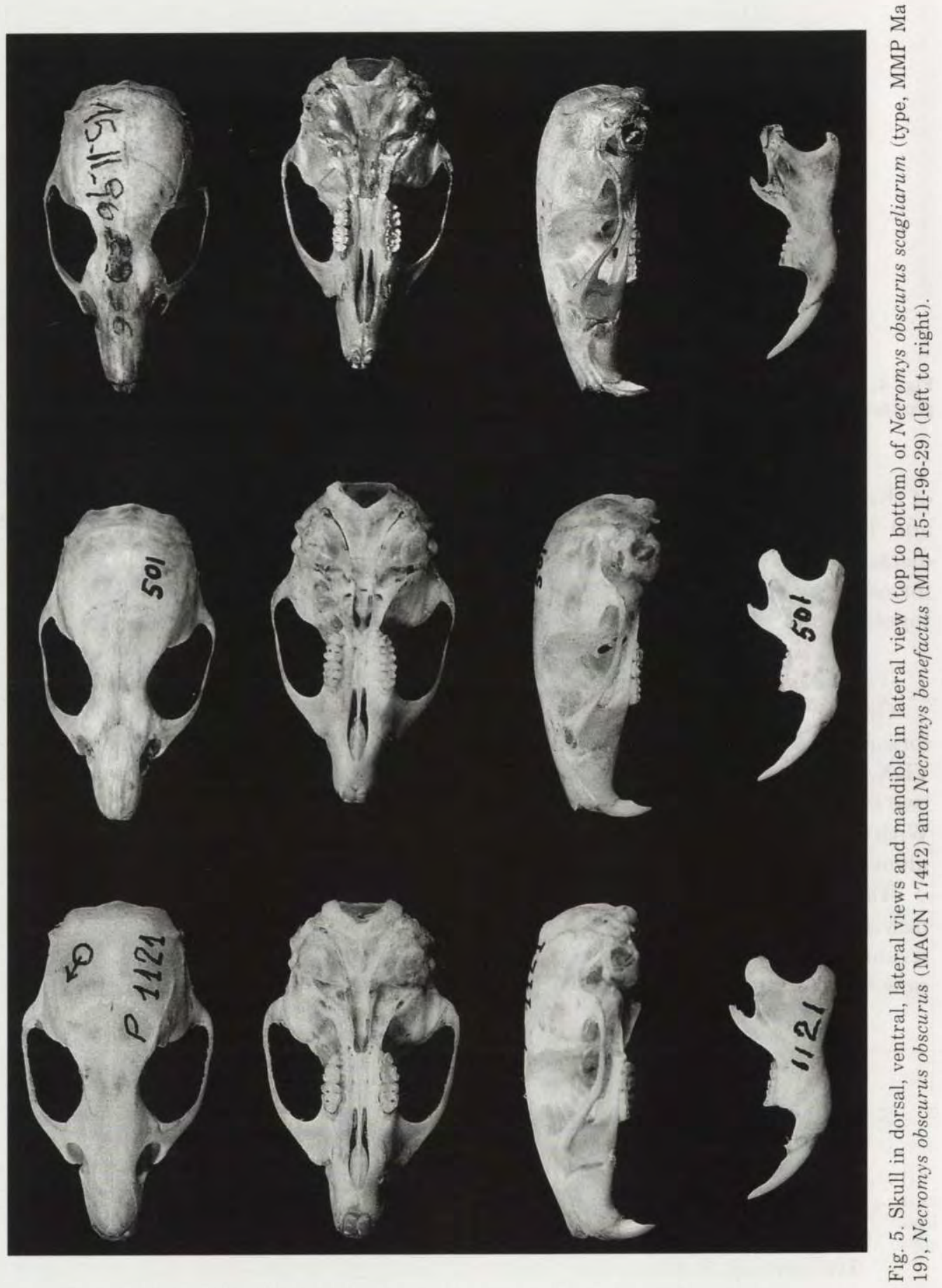


E t y molog y: Dedicated to Lorenzo, Galileo, and Orlando Scaglia - grandfather, father, and son - who during more than one-half a century have practiced paleontology on the Atlantic Coast of Buenos Aires Province. The specific epithet used by Reig (1972) in his unpublished thesis is validated here.

$\mathrm{H}$ o l o t y p e: Adult male, MMP Ma 19 from the mouth of Arroyo Corrientes, Mar del Plata ( $38^{\circ} 01^{\prime} \mathrm{S}, 5^{\circ} 31^{\prime} 30^{\prime \prime} \mathrm{W}$, General Pueyrredón county, Buenos Aires Province, Argentina). Collected by O. E. Donadío on 8 February 1974. The holotype is a skin with skull, mandibles, and long bones well preserved.

$\mathrm{H}$ y p od ig m: the holotype and specimens examined listed in the Appendix (localities \#14-22).

$\mathrm{Holotype}$ measurements: linear measurements (in mm): HBL = $113, \mathrm{TL}=57, \mathrm{EL}=14, \mathrm{HFL}=22 / 25.1, \mathrm{CBL}=27.97, \mathrm{DIL}=7.85, \mathrm{PAL}=12.99$, $\mathrm{WP} 1=3.46, \mathrm{WP} 2=2.47, \mathrm{IFL}=6.58, \mathrm{IFW}=1.81, \mathrm{ROB}=5.48, \mathrm{ROL}=10.23, \mathrm{IOC}$ $=4.88, \mathrm{BZW}=16.67, \mathrm{NAL}=8.59, \mathrm{FRL}=10.57, \mathrm{MFW}=1.15, \mathrm{BCW}=13.08, \mathrm{EPF}$ $=6.85, \mathrm{ZPW}=3.2, \mathrm{ZPH}=5.6, \mathrm{NAW}=3.71, \mathrm{MAL}=16.15, \mathrm{DLI}=3.79, \mathrm{M}^{1} \mathrm{~L}=$ $2.47, \mathrm{M}^{1} \mathrm{~W}=1.52, \mathrm{M}^{2} \mathrm{~L}=1.60, \mathrm{M}^{2} \mathrm{~W}=1.48, \mathrm{M}^{3} \mathrm{~L}=1.04, \mathrm{M}^{3} \mathrm{~W}=1.28, \mathrm{M}_{1} \mathrm{~L}=2.08$, $\mathrm{M}_{1} \mathrm{~W}=1.32, \mathrm{M}_{2} \mathrm{~L}=1.68, \mathrm{M}_{2} \mathrm{~W}=1.44, \mathrm{M}_{3} \mathrm{~L}=1.52, \mathrm{M}_{3} \mathrm{~W}=1.12, \mathrm{UMR}=5.61, \mathrm{LMR}$ $=5.69$; weight $=55 \mathrm{~g}$.

H y p o dig m m e a s u r e m e $\mathrm{t}$ s: see Table 1 (groups SES and TAN).

$\mathrm{D}$ i a $\mathrm{g} \mathrm{n}$ o s i s: Slightly smaller than $N$. o. obscurus in cranial size but with more robust molars; nasals flat in their anterior one-third, without covering completely the anterior end of the premaxilla; rounded nasofrontal suture, level with the orbital process of the maxilla; frontal edges in the interorbital constriction diverging no more than $20^{\circ}$ with respect to the mid-line; fronto-parietal suture open, U-shaped; mesopterygoid fossa U-shaped; mandible with robust, short, and slightly backward curved coronoid process; very well developed capsular projection, in labial view covering the base of the sigmoid notch; $\mathrm{M}^{1}$ procingulum fan-shaped.

D is t r i b u t i o n: Southeastern Buenos Aires Province (Argentina) between Santa Clara del Mar and Necochea localities and the southern end of Tandilia ranges (Figs 2 and 8 ).

$\mathrm{D}$ e s c r i p t i o n: This description is based on the entire series (including the holotype) and is restricted to the features that allow us to separate the subspecies from the remaining representatives of the genus in this area. Massoia and Fornes (1967) and Reig (1987) presented additional details of external and cranial features.

E x t e r n a $1 \mathrm{f} \mathrm{e} \mathrm{a} \mathrm{t} \mathrm{u} \mathrm{re} \mathrm{s:} \mathrm{The} \mathrm{back} \mathrm{of} N$. obscurus scagliarum has numerous long guard hairs $(13 \mathrm{~mm}$ ), blackish (saturate monochromatic eumelanin sensu Hershkovitz 1990), intermingled with shorter hairs, lead-colored at the base, reddish in the middle and blackish at the end (modified agouti sensu Hershkovitz 1990). This results in a dark-reddish coloring. Body sides are ochraceous and intergrade toward a yellowish gray ventrally, the thoracic region markedly ochraceous. The sides of the mouth and cheeks are orange. In contrast, $N$. benefactus has covering hairs similar in color but shorter $(9-10 \mathrm{~mm})$ and less dense; in the short hair, the pheomelanin portion is yellowish, giving the back an agouti color. 

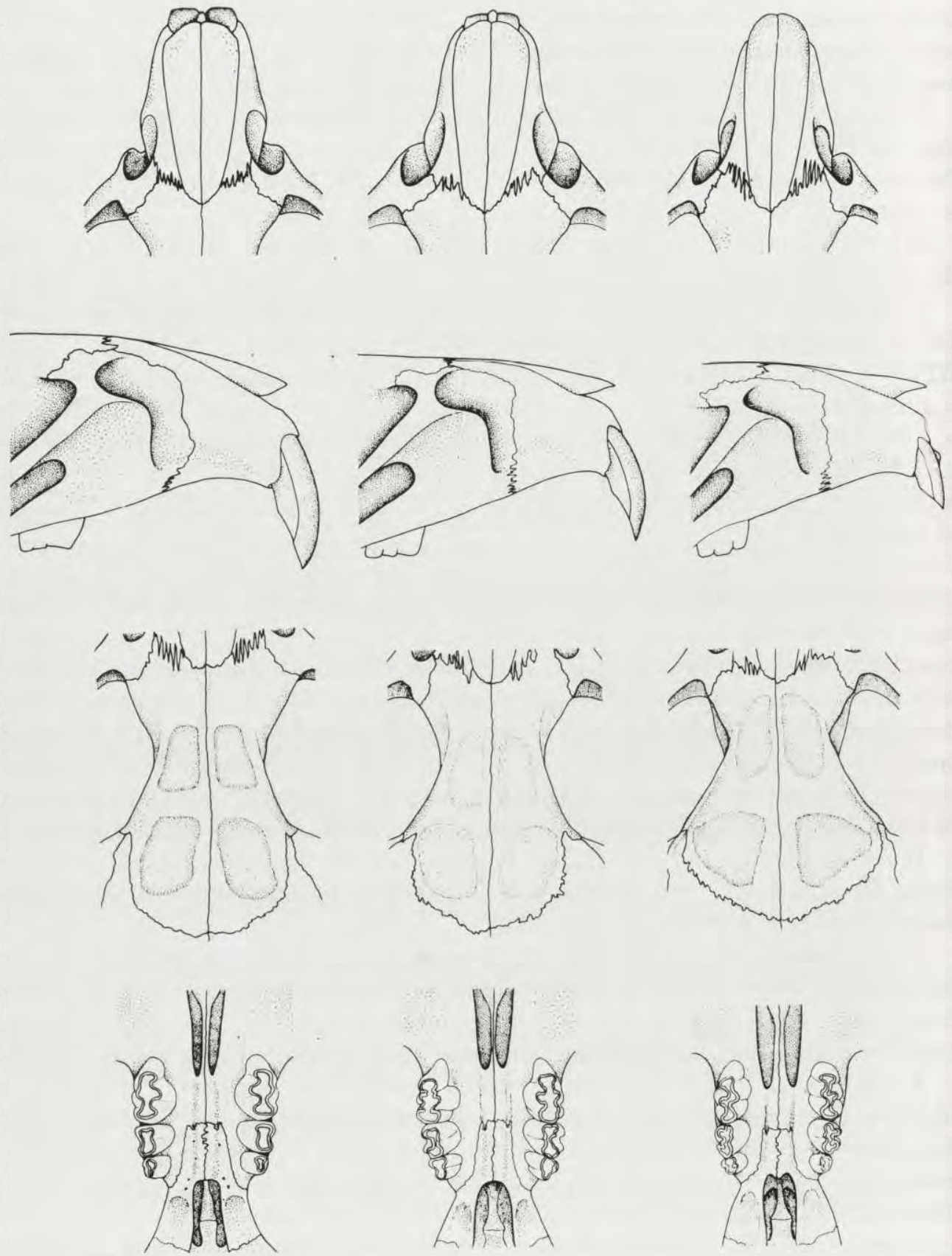

Fig. 6. Rostral, zygomatic, interorbital, and palatal regions (from top to bottom) of Necromys obscurus scagliarum, N. o. obscurus, and $N$. benefactus (from left to right). 
The sides of the body are yellowish gray and the abdomen is whitish gray, whereas the gular and inguinal regions are white.

M a n dible (Fig. 5): Robust and moderately high. The capsular projection, centrally placed between the coronoid process and the condyle, is well developed (in $N$. o. obscurus, it is somewhat smaller and directed toward the condyle) with a rounded apex and covering partially the sigmoid notch in lateral view. The coronoid process is robust, wide-based and slightly curved distally. The mandible of $N$. benefactus is like the skull, gracile and low. The capsular projection is small and lies on the condyle; the coronoid process is long and slender with its end completely curved backward.

S k u 11 (Figs 5 and 6): Robust and moderately elongated, dome-shaped. Nasals planar, widened in their anterior one-third and short (premaxillaries can be seen dorsally); nasofrontal suture rounded and not enclosed deeply between the frontals, slightly in front of the upper root of the zygomatic arch. The zygomatic plate is high, wide and robust, its upper margin is bevel-shaped and the anterior one is straight. There is no clear interorbital constriction point. The frontals are scarcely divergent posteriorly ( $>20^{\circ}$ from the sagittal axis) and their edges are rounded slightly (only in old adult specimens can a crest be observed in its posterior third). The frontoparietal suture is open U-shaped. The posterior edges of the incisor foramina reach the $\mathrm{M}^{1}$ protocone. The mesopterygoid fossa is U-shaped, without medial palatine process. $N$. obscurus obscurus skulls are very similar, though some differences may be marked: frontoparietal suture is U-shaped but more open and nasals are somewhat longer than in N. o. scagliarum. In N. benefactus the skull is more gracile. Nasals are more forwardly projected, hiding the premaxillaries and incisors in dorsal view, and tending to be tubed in its anterior third (with certain geographic variation). The zygomatic plate is high and less robust than in $N$. obscurus scagliarum, with its dorsal margin shorter and slightly rounded in its antero-dorsal end. The interorbital constriction is conspicuous and the frontals are distinctly divergent $\left(>25^{\circ}\right)$ with a sharp overhanging shelf in its posterior half. The fronto-parietal suture is V-shaped. The mesopterygoid fossa is quadrangular, with a constant and well defined medial palatine process.

Mola r s (Fig. 7): the species of the genus Necromys are characterized by a conservative molar pattern. A general description was presented by Reig (1987) and Anderson and Olds (1989). The main difference between $N$. obscurus and N. benefactus is the form of the procingulum of $\mathrm{M}^{1}$. In the former, the procingulum is fan-shaped, whereas in the latter it is compressed anterior-posteriorly. Other differences, related to molar size and the frequency of some dental traits (eg metalophule/entolophulid, enterostyle/ectostylid), are examined in extant and fossil samples in a forthcoming paper.

$\mathrm{D}$ i s t r i b u t i o n (Figs 2 and 8): Necromys obscurus scagliarum is restricted to grasslands and edges of cultivated fields in southeast coast of Buenos Aires Province (Argentina). Most of the reference points (Reig 1965, Massoia and Fornes 1967) are located on the coast line. Consequently, their extension inland within this 


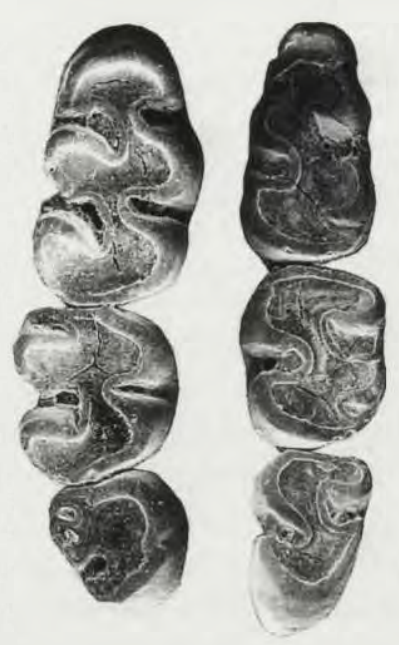

Fig. 7. Occlusal view of upper (left) and lower (right) molar rows of Necromys obscurus scagliarum (MMP Ma 19, type).

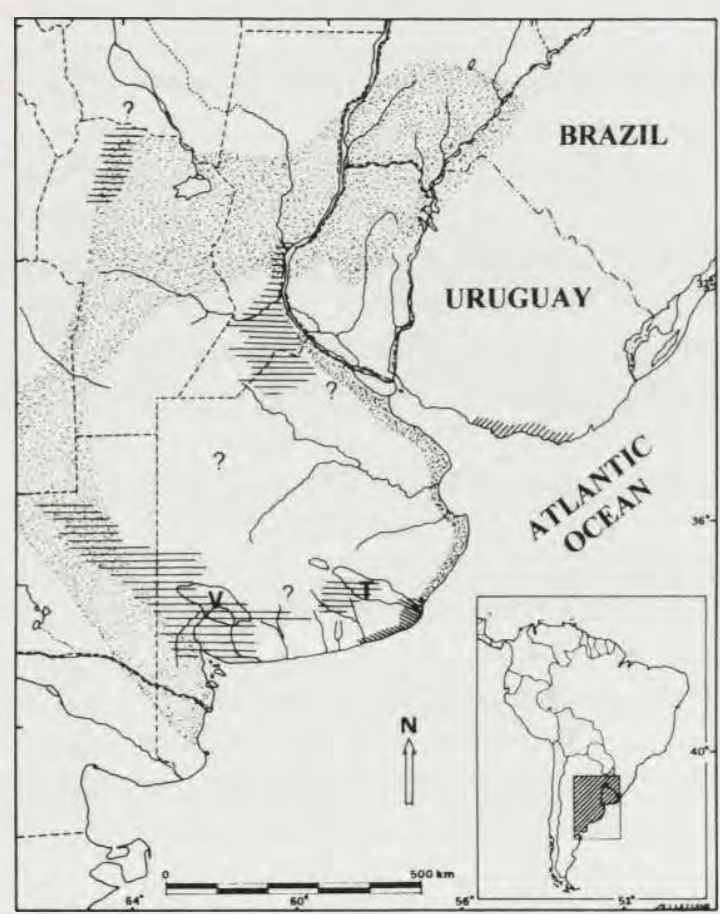

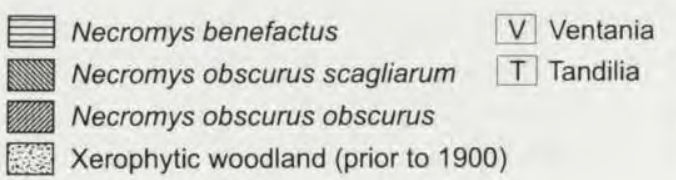

Fig. 8. Distribution of Necromys in central Argentina and Uruguay. Limits of the major vegetational units are superimposed (after Cabrera 1971). ? - uncertainty regarding presence of Necromys. 
province cannot be determined. Nonetheless, populations of this subspecies were observed in part of Tandilia ranges, at least up to the town of Balcarce (Fig. 2, locality \#22).

Necromys obscurus obscurus is distributed in southern Uruguay, in a restricted area along the Río de la Plata and Atlantic coast (San José, Montevideo, Canelones and Maldonado departments; E. González, pers. comm.). Information given by Barlow (1969) must be interpreted cautiously due to the morphological confusion between specimens of this species and Deltamys kempi.

Necromys benefactus is more widely distributed. The southernmost records in Buenos Aires Province reach the town of Bahía Blanca and Chasicó lagoon, within an ecotonal area between the phytogeographic units of the Espinal (predominantly covered with xerophytic woodland) and the pampean prairie (sensu Cabrera 1971). Farther north, it occurs in the Ventania ranges and in the bonaerian interserrana plain, reaching the Tandilia ranges by the east. There is no record of sympatry between $N$. obscurus and $N$. benefactus. However, the most southeastern locality of $N$. benefactus (Fulton) lies in the same ranges and less than $60 \mathrm{~km}$ away from Balcarce (the most northeastern locality of $N$. obscurus scagliarum). North of its type locality (Laguna Alsina $=$ Bonifacio Station), there are no records of $N$. benefactus in the whole sector known as "Pampa arenosa" ("Sandy Pampas"). The absence may be artifactual as it is one of the least sampled regions in Buenos Aires Province. In northeastern Buenos Aires and southern Santa Fé provinces, the number of localities increases, together with the intensity of studies on hosts of the Junín virus (Mills et al. 1991). In the remaining provinces (Córdoba and La Pampa), only isolated localities are known (Contreras and Justo 1974, Siegenthaler et al. 1993, Altrichter et al. 1994, Massoia et al. 1997). Two localities near the Rio de la Plata in Buenos Aires Province have capture data of $N$. benefactus before 1950s: San Miguel (Crespo 1944) and Monte Veloz (Merckle 1924 in schedis, MLP 11-II-36-8). Recent sampling has not recorded its presence at those places.

The absence of Necromys in Entre Ríos Province (Argentina) is noteworthy, as it lies between distributions of $N$. benefactus and $N$. obscurus obscurus.

\section{Discussion}

The taxonomic history of Necromys is one of the most complex among the sigmodontines (see Reig 1987, Massoia and Pardiñas 1993). Waterhouse (1837) described Mus obscurus based upon materials collected by Darwin at Maldonado, Uruguay. Thomas (1916) erected the genus Bolomys, then comprising B albiventer, $B$. berlepschii Thomas, 1898, and the type species B. amoenus. Later, Thomas (1919) named Akodon benefactus from Bonifacio (= Laguna Alsina), Buenos Aires Province, and noted its similarity to Akodon obscurus and A. lenguarum, a species he described in 1898 from northern Paraguay. These three taxa were considered by Hershkovitz (1962) as pertaining to the "southern group" of Zygodontomys. After a detailed study, Massoia and Fornes (1967) described Cabreramys, to include these 
three species. Reig $(1972,1978,1987)$ demonstrated the synomymy of Cabreramys with Bolomys and included in the genus B. amoenus, $\dagger B$. bonapartei, B. lactens, B. lasiurus, B. lenguarum, B. obscurus and B. temchuki.

Despite Reig's (1987) effort to clarify the systematics and nomenclature of this group of species, there was still another related taxon that had gone unnoticed. Ameghino (1889) described the genus Necromys (type species $N$. conifer) based upon a hemimaxilla from the upper Pleistocene of northern Buenos Aires Province. Hershkovitz (1962) considered this genus a synonym of Calomys. Massoia (1985) and later Massoia and Pardinas (1993) revalidated Necromys, after studying the original remain and designating it as lectotype. Necromys therefore being the first valid generic name for the species of Bolomys (sensu Reig 1987). Although the lectotype of $N$. conifer is fragmentary, it has the dental features that clearly associate it with the species $N$. benefactus, $N$. obscurus, $N$. lenguarum, $N$. lactens, $N$. lasiurus, $N$. punctulatus and N. temchuki (see Massoia and Pardiñas 1993, plate III, figure 1). The study of new Pleistocene remains from northeastern Buenos Aires Province allows us to determine $N$. conifer as the senior synonym of $N$. benefactus and to reject the earlier conclusion of nomen dubium given to the type species by Massoia and Pardiñas (1993). However, the replacement of the traditionally used name would introduce undesirable consequences, according to the recomendations of the ICZN [1985, Arts. 23 (b) and 79 (c)]. Consequently, the use of $N$. benefactus is retained in the interests of nomenclatural stability.

Bolomys albiventer (including B. berlepschii) belongs in the genus Akodon (Reig 1987). Akodon leucolimnaeus Cabrera, 1926 was considered conspecific with Necromys lactens by Gyldenstolpe (1932), Cabrera (1961), and subsequent authors (Reig 1987, Hershkovitz 1990). Reexamination of the holotype has allowed us to revalidate it as a species of Akodon (Galliari and Pardinas 1995). The systematic status of both Bolomys negrito Thomas, 1926 and B. orbus Thomas, 1919, included by Cabrera (1961) as synonyms of $N$. lactens, is dubious.

A different and significant problem is the status of Bolomys amoenus, type species of the genus. Results of Smith and Patton (1993), based on sequence date from the mitochondrial cytochrome-b gene, indicated that Necromys is paraphyletic if $B$. amoenus is considered congeneric. Until further study, Bolomys is considered in this paper as a partial synonym of Necromys, and the former retains the type species.

Results of our morphological analysis reinforce the taxonomic and distributional hypothesis of Massoia and Fornes (1967) for the pampean species of Necromys (Fig. 8). Two species of Necromys inhabit the middle latitudes of Argentina: (1) N. obscurus scagliarum restricted to the southeastern of Buenos Aires Province and (2) $N$. benefactus, with a wider distribution, from the southwestern interserrana area, western and northeastern parts of this province, eastern of La Pampa Province, south of Santa Fé Province, and northern of Córdoba Province. In turn, $N$. obscurus obscurus occupies southern Uruguay.

Populations of $N$. benefactus also show a sligth morphometric differentiation (Fig. 3a) that may justify subspecific separation. However, the constancy of 
numerous morphological characters, such as the mesopterygoid fossa, the interorbital and frontal areas, the molar structures, and the development of the ascending ramus of the mandible in the whole distributional range (ca $8^{\circ}$ latitude) lead us to refer them to a single species.

The specimens from northern Córdoba Province, although similar to $N$. benefactus, may represent a different species. These collection localities are in the southern Chacoan region, unlike the remaining populations of $N$. benefactus in the Espinal and part of the pampas. Farther north, in Chaco Province, lives $N$. lenguarum (see Galliari et al. 1996). Thomas (1916) emphasized the similarity between this taxon and $N$. benefactus. Further revisionary studies are needed for the populations inhabiting the Chacoan regions of Bolivia, Paraguay, and Argentina (see Anderson and Olds 1989, Anderson 1997).

The landscape of the pampean region, particularly eastern Buenos Aires and southern Santa Fé, has been strongly modified by humans, especially in the past 150 years (Crespo 1966). This alteration obscures possible causal relations between the present distributional patterns of muroid rodents and the vegetation. Although there are studies of changes in rainfall and temperature that occurred in this region during the present century (González 1995), information on the environment, fauna, and vegetation of the period prior to intensive farming and overgrazing is very scarce. This prevents any detailed knowledge on the magnitude of recent changes in distributions of many small mammals.

The modern distribution of $N$. benefactus seems to be associated with lower rainfall in the west and southwest, and xeric formations (ie Celtis tala woodlands) in the north and northeast (Fig. 8). Judging from the Late Holocene fossil record, $N$. benefactus inhabited the coasts of the Río de la Plata (Buenos Aires Province), reaching the latitude of Mar del Plata and coexisting with $N$. obscurus in the same environments (Pardiñas 1999). Perhaps the collection at Monte Veloz in 1920 (see above) is a relict of this wider ancient distribution, and its retraction may be related both to climatic causes and the expansion of agriculture. Likewise, several fossil records (Lower Holocene) show the presence of $N$. benefactus in the Reconquista river basin, some $50 \mathrm{~km}$ north of the city of Buenos Aires, and during the $1940 \mathrm{~s}$, a population outbreak ("ratada") of this species was recorded at San Miguel (Crespo 1944). Today, numerous analyses of owl pellets (eg Massoia 1988, 1989) indicate its absence from these areas, which have become densely urbanized. These data suggest very recent changes in the distribution of this species.

The distribution pattern of $N$. obscurus, with markedly allopatric populations in a single continental region, invites a search for historical biogeographic causes. Many collections in southern Uruguay and central eastern Buenos Aires Province indicate that this restricted distribution is not due to poor sampling. In addition, both subspecies seem to be limited mainly to the littoral strip (except for the aforementioned hilly distribution of N.o. scagliarum). To understand this pattern, it is necessary to go back to the geographic setting of the upper Pleistocene ca 18000-20000 years ago. For the maximum Isotopic Stage 2 (Last Glaciation) a 
decrease in sea level fall of ca 110-120 m has been proposed (Clapperton 1993). The shore line would have shifted offshore approximately $150-200 \mathrm{~km}$ along the Argentine and Uruguayan coasts, minimizing the barrier effect originated by the Paraná-de la Plata fluvial system. It may be supposed that $N$. obscurus could have had a continuous distribution along this paleocoast. Later, the establishment of the present climatic conditions in the Holocene, together with the middle Holocene transgression (ca 7000-6000 years ago) would have separated the populations that lead to the present allopatric setting.

The ongoing morphological study of all species of Necromys in Argentina and Uruguay allows the recognition of two groups: one formed by $N$. benefactus, $N$. lactens, $N$. lenguarum, $N$. lasiurus and $N$. temchuki, and another by $N$. obscurus. The group of species allied to $N$. benefactus is characterized by small to medium size (relative to $N$. obscurus) in cranial, mandibular, and dental measures, a well-defined interorbital constriction with frontals divergent posteriorly, with crested and sharp edges, frontoparietal suture V-shaped, mesopterygoid fossa with medial process, articular condyle depressed with gracile coronoid process, and capsular projection less developed. In contrast, the $N$. obscurus group (to which $N$. arviculoides may be added) is characterized by larger size, interorbital constriction less defined, frontals less divergent with smooth edged, frontoparietal suture U-shaped, mesopterygoid fossa without median process and U- or V-shaped, high articular condyle, robust coronoid process, and well developed capsular projection.

The available cytogenetic information indicates that the species of Necromys have a stable karyotype in number and gross morphology (Vitullo et al. 1986, Reig 1987). However, these authors noted differences in G-band patterns among some species. Karyotypes reported by Bianchi et al. (1971) for $N$. obscurus included specimens of both $N$. o. scagliarum and $N$, benefactus. Given the taxonomic hypothesis presented here, re-analysis of the cytogenetics of this genus is needed.

Elucidating the systematics and historical biogeography of Necromys is fundamental in view of the rapid man-made changes of the Argentine pampean region and southern Uruguay. The loss of biodiversity in these biomes, together with the outbreak of diseases, like the hantavirus or the hemorrhagic fever of Junin (the vectors of which are sigmodontine rodents), amplify the need to increase the knowledge of the mastofauna, in its taxonomic, distributional, and historic aspects. This challenge is attainable only through comprehensive synthesis of different investigational approaches, among which morphometry and comparative morphology are fundamental.

Acknowledgements: We are grateful to the curators O. Vaccaro and M. Piantanida (MACN), E. Massoia (CEMF), J. Polop, C. Provensal and M. Morando (UNRC), O. Scaglia, A. Dondas and D. Romero (MMP), M. Coccia (UNC), A. Mones and J. González (MNHNM), and E. Lessa, F. Hoffman and M. Clara (Facultad de Ciencias, Montevideo). E. González (MNHNM) and S. Tiranti (Universidad Nacional de La Pampa) gave us freely unpublished information on the distribution of Necromys in Uruguay and La Pampa, respectively. S. Steppan, R. Voss, M. Carleton and two anonymous reviewers provided helpful comments. This study was supported by Consejo Nacional de Investigaciones Científicas y Técnicas, a grant of the Facultad de Ciencias Naturales y Museo (Universidad Nacional La Plata), and the FOSDIC Foundation. 


\section{References}

Altrichter M., Kufner M., Giraudo L., Gavier G., Tamburini D. and Sironi M. 1994. Variación temporal y espacial de comunidades de pequeños mamíferos en la Reserva La Quebrada, Río Ceballos. IX Jornadas Argentinas de Mastozoologia, Resúmenes: 13.

Ameghino F. 1889, Contribución al conocimiento de los mamíferos fósiles de la República Argentina. Actas de la Academia Nacional de Ciencias en Córdoba 6: 1-1027 \& Atlas: 98 pls.

Anderson S. 1997. Mammals of Bolivia, taxonomy and distribution. Bulletin of the American Museum of Natural History 231: 1-652.

Anderson S. and Olds N. 1989. Notes on Bolivian mammals. 5. Taxonomy and distribution of Bolomys (Muridae, Rodentia). American Museum Novitates 2935: 1-22.

Barlow J. C. 1969. Observations on the biology of rodents in Uruguay. Life Sciences Contributions, Royal Ontario Museum 75: 1-57.

Bianchi N. O., Reig O. A., Molina J. and Dulout F. N. 1971. Cytogenetics of South American akodont rodents (Cricetidae). I. A progress report of Argentinian and Venezuelan forms. Evolution 21: 724-736.

Braun J. K. and Mares M. A. 1995. A new genus and species of phyllotine rodent (Rodentia: Muridae: Sigmodontinae: Phyllotini) from South America. Journal of Mammalogy 76: 504-521.

Cabrera A. 1961. Catálogo de los mamíferos de América del Sur. Parte II. Revista del Museo Argentino de Ciencias Naturales "Bernardino Rivadavia”. Ciencias Zoológicas 4: 309-732.

Cabrera A. L. 1971. Fitogeografia de la República Argentina. Boletín de la Sociedad Argentina de Botánica 16: 1-42.

Clapperton C. M. 1993. Quaternary geology and geomorphology of South America. Elservier, Amsterdam: 1-779.

Contreras J. R. and Justo E. 1974. Aportes a la mastozoología pampeana. I. Nuevas localidades para roedores Cricetidae (Mammalia, Rodentia). Neotrópica 20: 91-96.

Crespo J. A. 1944. Relaciones entre estados climáticos y la ecología de algunos roedores de campo (Cricetidae). Revista Argentina de Zoogeografía 4: 137-144.

Crespo J. A. 1966. Ecología de una comunidad de roedores silvestres en el partido de Rojas, provincia de Buenos Aires. Revista del Museo Argentino de Ciencias Naturales "Bernardino Rivadavia" e Instituto Nacional de Investigación de las Ciencias Naturales, Ecología 1: 79-144.

Galliari C. A. and Pardiñas U. F. J. 1995. La identidad de Akodon leucolimnaeus Cabrera (Rodentia, Sigmodontinae). X Jornadas Argentinas de Mastozoología, Resúmenes: 28.

Galliari C. A., Pardiñas U. F. J. and Goin F. J. 1996. Lista comentada de los mamíferos de la Argentina. Mastozoología Neotropical 3: 39-61.

González M. A. 1995. Diagnóstico ambiental de la provincia de Buenos Aires. Tomo I: aspectos básicos. Ediciones Banco Provincia, Buenos Aires: 1-245.

Gyldenstolpe N. 1932. A manual of Neotropical sigmodont rodents. Kungliga Svenska Vetenskapsakademiens Handlingar 3: 1-164.

Hershkovitz P. 1962. Evolution of Neotropical cricetine rodents (Muridae), with special reference to the phyllotine group. Fieldiana: Zoology 46: 1-524.

Hershkovitz P. 1990. Mice of the Akodon boliviensis size class (Sigmodontinae, Cricetidae), with the description of two new species from Brazil. Fieldiana: Zoology (new series) 57: 1-35.

International Commission on Zoological Nomenclature. 1985. International code of zoological nomenclature adopted by the XX General Assembly of the International Union of Biological Sciences. International Trust for Zoological Nomenclature, London: $x x+1-338$.

Legendre L. and Legendre P. 1983. Numerical ecology. Developments in Environmental modelling, 3. Elsevier Scientific Publishing Company, New York: 1-419.

Macedo R. H. and Mares M. A. 1987. Geographic variation in the South American cricetine rodent Bolomys lasiurus. Journal of Mammalogy 68: 578-594. 
Marcus L. 1990. Traditional morphometrics. [In: Proceedings of the Michigan Morphometrics Workshops. F. J. Rohlf and F. L. Bookstein, eds]. The University of Michigan Museum of Zoology, Ann Arbor, Special Publication 2: 77-122.

Massoia E. 1976. Mammalia. [In: Fauna de agua dulce de la República Argentina. R. Ringuelet, ed]. Fundación Editorial Ciencia y Cultura, Buenos Aires 44: 1-128,

Massoia E. 1985. El estado sistemático de algunos muroideos estudiados por Ameghino en 1889 con la revalidación del género Necromys (Mammalia, Rodentia, Myomorpha). Circular Informativa, Asociación Paleontológica Argentina 14: 4.

Massoia E. 1988. Análisis de regurgitados de Tyto alba de Ituzaingo, partido de Morón, provincia de Buenos Aires. Boletín Científico, Asociación para la Protección de la Naturaleza 2: 13-20.

Massoia E. 1989. Animales depredados por Tyto alba tuidara en la ciudad de San Miguel, partido de General Sarmiento, provincia de Buenos Aires. Boletín Científico, Asociación para la Protección de la Naturaleza 15: 2-7.

Massoia E. and Fornes A. 1967. El estado sistemático, distribución geográfica y datos etoecológicos de algunos mamíferos neotropicales (Marsupialia y Rodentia) con la descripción de Cabreramys, género nuevo (Cricetidae). Acta Zoológica Lilloana 23: 407-430.

Massoia E. and Pardiñas U. F. J. 1993. El estado sitemático de algunos muroideos estudiados por Ameghino en 1889. Revalidación del género Necromys (Mammalia, Rodentia, Cricetidae). Ameghiniana 30: 407-418.

Massoia E., Tiranti S. and Diéguez A. 1997. Pequeños mamíferos depredados por Tyto alba en la provincia de La Pampa, según sucesivas recolecciones. Boletín Científico, Asociación para la Protección de la Naturaleza 32: 19-21.

Mills J. N., Ellis B. A., McKee K. T., Maistegui J. I. and Childs J. E. 1991. Habitat associations and relative densities of rodent populations in cultivated areas of central Argentina. Journal of Mammalogy 72: 470-479

Musser G. G. and Carleton M. D, 1993. Family Muridae. [In: Mammal species of the world: a taxonomic and geographic reference. D. E. Wilson and D. M. Reeder, eds]. Smithsonian Institution Press, Washington, D.C.: 501-755.

Pardinas U. F. J. 1999. Fossil murids: taxonomy, palaeoecology, and palaeoenvironments. Quaternary of South America and Antarctic Peninsula 12: 225-254.

Patterson B. D. 1992. A new genus and species of long-clawed mouse (Rodentia: Muridae) from temperate rainforests of Chile. Zoological Journal of the Linnean Society 106: 127-145.

Reig O. A. 1965. Datos sobre la comunidad de pequeños mamíferos de la región costera del partido de General Pueyrredón y los partidos limítrofes. Physis 25: 205-211.

Reig O. A. 1972. The evolutionary history of the South American cricetids rodents. Ph D thesis, University of London, London: 1-451.

Reig O. A. 1978. Roedores cricétidos del Plioceno superior de la provincia de Buenos Aires (Argentina), Publicaciones del Museo Municipal de Ciencias Naturales "Lorenzo Scaglia" 2: 164-190.

Reig O. A. 1987. An assessment of the systematics and evolution of the Akodontini, with the description of a new fossil species of Akodon (Cricetidae: Sigmodontinae), Fieldiana: Zoology (new series) 39: $347-399$

Reig O. A. 1994. New species of akodontine and scapteromyine rodents (Cricetidae) and new records of Bolomys (Akodontini) from the upper Pliocene and middle Pleistocene of Buenos Aires Province, Argentina. Ameghiniana 31: 99-113.

Santos Moreno J. A. 1994. Evaluación del uso de las medidas externas estándar en los análisis morfométricos de mamíferos. Anales del Instituto de Biología de la Universidad Nacional Autónoma de México: Serie Zoología 65: 275-285.

Siegenthaler G. B., Tiranti S. I. and Duco C. M. 1993. Relevamiento de los vertebrados de la provincia de La Pampa. Tercer informe. V Jornadas Pampeanas de Ciencias Naturales 1: 139-147.

Smith M. F. and Patton J. L. 1993. The diversification of South American murid rodents: evidence from mitochondrial DNA sequence data for the akodontine tribe. Biological Journal of the Linnean Society 50: 149-177. 
Sokal R. R. and Rohlf F. J. 1981. Biometry: the principles and practice of statistics in biological research. Second ed. W. H. Freeman and Company, San Francisco: 1-859.

StatSoft, Inc. 1995. Statistica for Windows: computer program manual. StatSoft, Inc., Tulsa, Oklahoma: 1-564.

Thomas O. 1916. The grouping of the South American Muridae commonly referred to Akodon. The Annals and Magazine of Natural History, series 8, 18: 336-340.

Thomas O. 1919. Two new Argentine species of Akodon. The Annals and Magazine of Natural History, series 9, 3: 213-215.

Vitullo A. D., Merani M. S., Reig O. A., Kajon A. E., Scaglia O., Espinosa M. B. and Pérez-Zapata A. 1986. Cytogenetics of South American akodont rodents (Cricetidae): new karyotypes and chromosomal banding patterns of Argentinian and Uruguayan forms. Journal of Mammalogy 67: 69-80

Voss R. S. 1988. Systematics and ecology of ichthyomyine rodents (Muroidea): patterns of morphological evolution in a small adaptative radiation. Bulletin of the American Museum of Natural History 188: 259-493.

Voss R. S. 1991. On the identity of "Zygodontomys" punctulatus (Rodentia: Muroidea). American Museum Novitates 3026: 1-8.

Waterhouse G. R. 1837. Characters of new species of the genus Mus, from the collection of Mr. Darwin. Proceedings of the Zoological Society of London 5: 15-27.

Ximénez A., Langguth A. and Praderi R. 1972. Lista sistemática de los mamíferos del Uruguay. Anales del Museo Nacional de Historia Natural de Montevideo 7: 1-49.

Received 10 February 1999, accepted 17 August 1999. 
Appendix. List of collecting localities for Necromys from central Argentina and southern Uruguay. Specimens used in the morphometric analysis (*) are housed in the following institutions: Museo Argentino de Ciencias Naturales "Bernardino Rivadavia", División Mastozoología (MACN), Museo de La Plata, Departamento Científico Zoología Vertebrados (MLP), Universidad Nacional del Centro (Tandil), Facultad de Veterinaria (UNC), Universidad Nacional de Río Cuarto, Córdoba (UNRC), Museo Municipal de Ciencias Naturales de Mar del Plata "Lorenzo Scaglia" (MMP Ma), Museo de Historia Natural de Montevideo, Uruguay (MHNM), and Colección de Mamíferos de Elio Massoia and family (CEMF). Map position of localities is show in Fig. 2. $\sigma$ - male,, - female. ? - sex undetermined.

Argentina, Buenos Aires Province: 1 - Laguna Chasicó (MACN 15628 \&, MLP 20-V-77-1 $\sigma$, 20-V-77-3 ?, 20-V-77-2 o); 2 - Bahía Blanca (owl pellets); 3 - Monte Hermoso (owl pellets); 4 - Coronel Dorrego (MMP Ma 117 ?); 5 - Sierra de la Ventana * (MLP 15-II-96-46 o, 15-II-96-45 $\sigma, 15-$ II-96-41 $\sigma$,

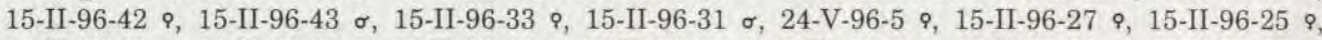
15-II-96-23 $\sigma, 15-$ II-96-22 $\sigma, 15-$ II-96-26, , 15-II-96-12 $\sigma, 15-$ II-96-10, 15-II-96-11 $\sigma, 15-I I-96-17 \%$, 15-II-96-18 o, 15-II-96-19 ९, 24-V-96-3 o, 15-II-96-15 o, 15-II-96-16 ९, 15-II-96-14 9, 15-II-96-13 ?,

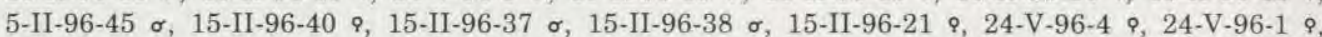
15-II-96-30 $\sigma, 15-$ II-96-28, , 15-II-96-24 $\sigma, 15-$ II-96-20 $\sigma$, 15-II-96-32 ?, 15-II-96-29 $\sigma, 15-$ II-96-39 , 15-II-96-36 o, 15-II-96-47 ?, 15-II-96-44 ९); 6 - La Toma (owl pellets); 7 - Abra de la Ventana (owl pellets); 8 - Saavedra (owl pellets); 9 - Laguna Alsina (= Bonifacio) (type locality of N. benefactus); 10 - Villa El Cacique (owl pellets); 11 - Necochea (owl pellets); 12 - Centinela del Mar (cited by Reig 1965); 13 - Fulton (UNC 56A \&, 34B \&, 20A $\sigma, 51 \mathrm{~A} \sigma, 33 \mathrm{~B} \sigma, 32 \mathrm{~B}$ \%); 14 - Mar del Sur (cited by Reig 1965); 15 - Miramar (cited by Reig 1965); 16 - Arroyo Brusquitas * (MACN $17444 \sigma, 174649,17468 \sigma$,

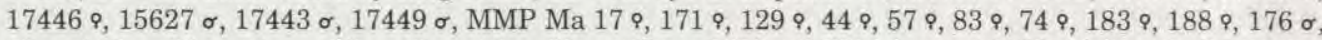
$26 \sigma, 113 \sigma, 70 \sigma, 21 \sigma, 129 \sigma, 53 \sigma, 19 \sigma, 20 \sigma, 253 \sigma$, MLP 30-VII-96-4 $\sigma, 30$-VII-96-3 $\sigma, 28-I X-95-2 \circ$, 30-VII-96-2 9,30 -VII-96-1 $\sigma, 19-\mathrm{V}-89-3 \sigma$ ); 17 - Terrazas del Marquesado y Playa los Lobos * (MMP Ma 361 ९, 276 ९, 373 ९, MLP 5-V-71-1 ?); 18 - Arroyo Corrientes, Mar del Plata * (type locality of $N$ obscurus scagliarum; MMP Ma 19 o type, 216 ९); 19 - Santa Clara del Mar (owl pellets); 20 - Laguna de los Padres * (MMP Ma 299 $\sigma, 310 \sigma, 313$ ९); 21 - Sierra de los Difuntos * (MMP Ma 451 ९, $429 \sigma$,

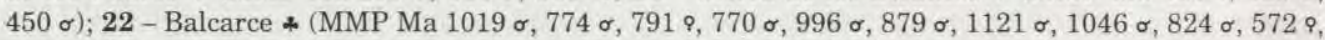
148 o, 835 б, MLP 5-XI-92-15 9); 23 - Monte Veloz (MLP 11-II-36-8 ?); 24 - San Miguel (cited by Crespo 1944); 25 - Rojas * (MACN 14398 o, 18155 \&, $18142 \sigma, 18154 \sigma, 18156 \sigma, 18153$ \%, 18150 o, 18158 \%, $18151 \sigma, 18160 \sigma, 18157 \sigma, 18140$ \&, $18147 \sigma, 18141$ \&, 14394 ?, $14648 \sigma, 14393$ \&, 14647 ९, $14654 \sigma$, $14646 \sigma, 14652 \sigma, 14653$ ᄋ, $14655 \sigma, 18144$ ९, $18149 \sigma$, MLP 12-VIII-71-5 ?); 26 - Rancagua (cited by Massoia and Fornes 1967); 27 - Fontezuela (cited by Massoia and Fornes 1967); 28 - Pergamino * (MACN $17485 \sigma, 18780 \sigma$, CEMF $1956 \sigma, 8133 \circ, 1952$, $1930 \sigma, 8131 \sigma, 1510 \sigma, 8132$, $8141 \sigma, 8136 \sigma$, $8135 \sigma, 1951$ ९, $1965 \sigma) ; 29$ - Acevedo (cited by Massoia and Fornes 1967); 30 - Ramallo (owl pellets).

Santa Fé Province: 31 - Weelwright (cited by Mills et al. 1991); 32 - Chovet (MACN 18713 o); 33 Arteaga (cited by Mills et al. 1991); 34 - San José de la Esquina (cited by Mills et al. 1991); 35 - Casilda (cited by Mills et al. 1991); 36 - Alcorta (cited by Mills et al. 1991); 37 - Bigand (MACN 18715 \%); 38 Máximo Paz (cited by Mills et al. 1991); 39 - Uranga (MACN 18706 o, 18710 \&, 18702 o); 40 - General Gelly (cited by Mills et al. 1991); 41 - J. B. Molina (cited by Mills et al. 1991); 42 - Rosario (owl pellets); 43 - Oliveros (cited by Mills et al. 1991); 44 - Maciel (cited by Mills et al. 1991); 45 - Santa Fé (cited by Mills et al. 1991); 46 - Colonia Esperanza (MACN 16554 \&, 16555 o).

Córdoba Province: 47 - Río Ceballos (cited by Altrichter et al. 1994); 48 - Villa de María (UNRC 8598 ९, $8618 \sigma, 8616 \sigma, 8617$ o); 49 - Pozo del Tigre (MACN 14730 \&, 14729 \&, 14735 \&, $14715 \sigma$ ).

La Pampa Province: 50 - Luan Toro (Universidad Nacional de La Pampa, 3 specimens unnumbered); 51 - Bajo La Pala (cited by Siegenthaler et al. 1993); $\mathbf{5 2}$ - Quehué (cited by Contreras and Justo 1974); 53 - Laguna Guatraché (cited by Massoia et al. 1997).

Uruguay, San José Department: 54 - Arroyo del Tigre (owl pellets); 55 - Barra del río Santa Lucía (owl pellets).

Montevideo Department: 56 - Parque Lecocq * (MNHNM 3545 o, 3559 o, 3549 q); 57 - Bañados de Carrasco (owl pellets).

Canelones Department: 58 - Arroyo Tropa Vieja * (MACN 17442 o, MNHNM 3568 o); 59 Laguna del Cisne * (MNHNM 440 9).

Maldonado Department: 60 - Maldonado (type locality of $N$. obscurus obscurus). 